\title{
Automated model optimization to study spike shape modulation in Layer 2/3 cortical pyramidal neurons
}

\author{
Michael Vella*, Hugh PC Robinson \\ From Twenty First Annual Computational Neuroscience Meeting: CNS*2012 \\ Decatur, GA, USA. 21-26 July 2012
}

It has been proposed that, contrary to the "classical" view in which cortical action potentials are encoded as purely digital, all-or-none events, action potential (AP) shape may be used by the brain for representing and processing information [1-4]. Cortical pyramidal neurons of Layer $2 / 3$ show prominent variations in AP waveform during sustained depolarizing responses, which may lead to different levels of synaptic output at proximal axonal synaptic terminals, and different patterns of invasion of the dendrites by back-propagating APs. A range of membrane ionic channels probably plays an important part in this phenomenon. We carried out electrical recording during conductance injection, combined with morphological reconstruction and multicompartmental modelling of Layer II/III pyramidal neurons in rat and mouse cortical slices, to investigate the mechanism of AP waveform modulation. Evolutionary optimization techniques [5-7] were implemented and a computational cluster architecture was designed for searching the parameter space of ion channel distributions and properties efficiently in parallel, to fit models to experimental data. As a test of the fitting process, we assessed its ability to detect point voltage-dependent conductances of different types, introduced at the soma by conductance injection (dynamic clamp). Using the available evidence, we describe how the inactivation kinetics of voltage-dependent potassium channels appears to play a particularly important role in the modulation of action potential waveform of these neurons.

Published: 16 July 2012

\footnotetext{
* Correspondence: mv333@cam.ac.uk

Department of Physiology,Development and Neuroscience, University of Cambridge, Cambridge, CB2 3DY, UK
}

(c) 2012 Vella and Robinson; licensee BioMed Central Ltd. This is an Open Access article distributed under the terms of the Creative Commons Attribution License (http://creativecommons.org/licenses/by/2.0), which permits unrestricted use, distribution, and reproduction in any medium, provided the original work is properly cited.
References

1. de Polavieja GG, Harsch A, Kleppe I, Robinson HPC, Juusola M: Stimulus history reliably shapes action potential waveforms of cortical neurons. J. Neurosci. 2005, 25:5657-65.

2. Alle H, Geiger JRP: Combined analog and action potential coding in hippocampal mossy fibers. Science 2006, 311:1290-3.

3. Shu Y, Hasenstaub A, Duque A, Yu Y, McCormick Da: Modulation of intracortical synaptic potentials by presynaptic somatic membrane potential. Nature 2006, 441:761-5.

4. Juusola M, Robinson HPC, de Polavieja GG: Coding with spike shapes and graded potentials in cortical networks. BioEssays 2007, 29:178-87.

5. Markram H, Segev I, Hay E, Hill S, Schu F: Models of Neocortical Layer 5b Pyramidal Cells Capturing a Wide Range of Dendritic and Perisomatic Active Properties. PLoS Comp. Biol 2011, 7(7).

6. Druckmann S, Berger TK, Hill S, Schürmann F, Markram H, Segev I: Evaluating automated parameter constraining procedures of neuron models by experimental and surrogate data. Biol. Cybernetics 2008, 99:371-9.

7. Keren N, Bar-Yehuda D, Korngreen A: Experimentally guided modelling of dendritic excitability in rat neocortical pyramidal neurones. J. Physiol. 2009, 587:1413-37

doi:10.1186/1471-2202-13-S1-P57

Cite this article as: Vella and Robinson: Automated model optimization to study spike shape modulation in Layer $2 / 3$ cortical pyramidal neurons. BMC Neuroscience 2012 13(Suppl 1):P57.

Submit your next manuscript to BioMed Central and take full advantage of:

- Convenient online submission

- Thorough peer review

- No space constraints or color figure charges

- Immediate publication on acceptance

- Inclusion in PubMed, CAS, Scopus and Google Scholar

- Research which is freely available for redistribution 